\title{
Variations in rabbit oviduct microvascular architecture after ovulation induced by hCG
}

\author{
C. J. Verco*, B. J. Gannon† and W. R. Jones* \\ Departments of * Obstetrics and Gynaecology and + Human Morphology, Flinders Medical Centre \\ and The Flinders University of South Australia, Bedford Park, South Australia 5042, Australia
}

\begin{abstract}
Summary. Rabbits were induced to ovulate by injection with hCG and vascular corrosion casts of the oviducts were examined by scanning electron microscopy after 24 and $48 \mathrm{~h}$, when the ova would be expected to be at the ampullary-isthmic junction, and traversing the isthmus respectively. At $24 \mathrm{~h}$ there was dilatation of the isthmic subserosal venous plexus. It is suggested that venous distension in the isthmic subserosal venous plexus, due to raised venous pressure or to reduced venous wall tone, may occlude the isthmic lumen to ova, and thus explain the known pre-isthmic delay in ovum transport. By $48 \mathrm{~h}$ after hCG, distension was no longer evident, consistent with the possibility of ovum transport.
\end{abstract}

\section{Introduction}

Oestrous rabbits ovulate within $10 \cdot 25$ to $14 \mathrm{~h}$ of copulation or injection of hCG (Harper, 1963). Ova are transported to the ampullary-isthmic junction (AIJ) within $10 \mathrm{~min}$ of ovulation (Boling \& Blandau, 1971), where they remain for at least $24 \mathrm{~h}$ (Pauerstein, Anderson, Chatkoff \& Hodgson, 1974), before slowly moving through the isthmus to enter the uterine cavity some $63-66 \mathrm{~h}$ after hCG injection (Pauerstein et al., 1974). Ova are located entirely within the isthmus by $48 \mathrm{~h}$ after the ovulatory stimulus (Pauerstein et al., 1974). Two regions where isthmic tubal ovum transport is delayed have been suggested; firstly at the AIJ and secondly in the isthmus adjacent to the uterine horn (Pauerstein et al., 1974). The mechanism of delay preceding isthmic ovum transport has always aroused interest and suggested explanations include isthmic intraluminal mucus (Jansen, 1978), isthmic muscular activity (Blair \& Beck, 1976), isthmic mucosal oedema (Hodgson, 1978; Overström, Bigsby \& Black, 1980) and distension of the isthmic subserosal venous plexus (Verco, Gannon \& Jones, 1983a). Rabbit oviduct microvascular architecture has been examined in midpregnancy (Verco, et al., 1984) and after oophorectomy (Verco, et al., 1983b). Variations in venous distension have supported the proposal that alterations in isthmic subserosal venous pressure or venous smooth muscle tone (with resultant venous dilatation) may, by affecting isthmic luminal constriction, be relevant in the pre-isthmic delay in tubal ovum or embryo transport (Verco et al., 1983a).

This study was undertaken to document, by scanning electron microscopy (SEM) of corrosion vascular casts, variations in rabbit tubal microvasculature preceding and during isthmic ovum transport.

\section{Materials and Methods}

Young adult virgin female rabbits (Institute of Medical and Veterinary Science strain, Adelaide, South Australia), 2·3-3.2 kg, caged separately and fed ad libitum, received 100 i.u. hCG (Organon 
Australia Pty Ltd, New South Wales) injected into a marginal ear vein. After $24 \mathrm{~h}$ ( 5 rabbits) and $48 \mathrm{~h}$ ( 5 rabbits), vascular corrosion casts were prepared as described by Verco et al. (1983a). In this technique vascular casts were prepared, in anaesthetized rabbits, after aortic and inferior cava cannulation and blood washout with an electrolyte solution (Plasmalyte 148, Travenol Laboratories, Sydney) at $37^{\circ} \mathrm{C}$. To prevent extensive hind limb, renal and gut casting (with the consequent need for greater volumes of casting medium) the femoral and renal vessels were clamped and the aortic cannula ligated caudal to the renal vessels to prevent the cranial flow of casting medium. The casting medium consisted of pre-polymerized methyl methacrylate (Verco et al., 1983a) and was infused through the aortic cannula. Casts were allowed to set, for $1 \mathrm{~h}$, under slight positive intravascular pressure before uterotubal excision. Tubal tissue was removed by corrosion in concentrated $\mathrm{KOH}$. A further 12 virgin female rabbits, of similar age, served as uninjected controls to permit determination of normal tubal microvascular architecture; the results of these control studies have been published separately (Verco et al., 1983a). Casts suitable for further study were obtained from each oviduct. The cleaned, corroded casts were thoroughly wetted in distilled water, frozen in a domestic freezer and then cut with a single-edged razor blade. Cast specimens from the isthmus (proximal and distal to the uterotubal junction), ampulla (proximal and distal to the AIJ) and fimbria were dried in air, mounted on SEM stubs, sputter-coated with gold/palladium and examined in a scanning electron microscope (Autoscan, ETEC Corporation, Hayward, CA, U.S.A.) at $20 \mathrm{kV}$.

The other 4 rabbits, 2 at $24 \mathrm{~h}$ and 2 at $48 \mathrm{~h}$ after hCG injection, were treated as described previously (Verco et al., 1983a) by blood washout with a $3.5 \%$ colloid solution (Haemaccel, Hoechst Australia Limited, New South Wales). These rabbits were then perfused with $1 \%$ osmium tetroxide $\left(\mathrm{OsO}_{4}\right)$ dissolved in nearly isotonic $(350 \mathrm{mosmol})$ phosphate buffer $(\mathrm{pH} 7 \cdot 4)$ with $1.5 \%$ dextran added (Gil, Bachofen, Gehr \& Weibel, 1979). At $2 \mathrm{~h}$ after perfusion, the oviducts were excised and post-fixed for $24 \mathrm{~h}$ in phosphate-buffered $2.5 \%(\mathrm{w} / \mathrm{v})$ glutaraldehyde. The tubes were dehydrated in an alcohol series and cut transversely into small blocks with a new razor blade. The blocks were dehydrated in a critical-point dryer (Model H, Pelco, U.S.A.) mounted on SEM stubs, gold/palladium sputter-coated and the cut surfaces examined by SEM.

Stereopairs of photomicrographs, with $5^{\circ}$ tilt separation between each, were taken from all

\section{PLATE 1}

Figs 1 and 2. Longitudinal segment (Fig. 1) and transverse razor cut surface (Fig. 2) of a methacrylate corrosion vascular cast of the isthmus near the uterotubal junction of a rabbit $24 \mathrm{~h}$ after intravenous injection of hCG. Venous distension is clearly greater than that observed in Pl. 2, Figs 3 and 4. Isthmic luminal dilatation in Fig. 2 is similar to that in controls (Fig. 1 A: Verco et al., 1983a). v, vein; P, plical microvasculature; M, myosalpingeal microvasculature; $\mathrm{S}$, serosal microvasculature; $\mathrm{L}$, lumen.

\section{PLATE 2}

Figs 3 and 4. Longitudinal segment (Fig. 3) and transverse razor cut surface (Fig. 4) of a methacrylate corrosion vascular cast of the isthmus near the uterotubal junction of a rabbit $48 \mathrm{~h}$ after intravenous hCG injection. Venous distension is clearly less than that observed in Figs 1 and 2. v, vein; P, plical microvasculature; $\mathbf{M}$, myosalpingeal microvasculature; L, lumen.

\section{PLATE 3}

Figs 5 and 6. A razor cut surface (transverse section) of the isthmus (after osmium tetroxide vascular perfusion fixation) at $24 \mathrm{~h}$ (Fig. 5) and $48 \mathrm{~h}$ (Fig. 6) after hCG injection. The luminal dilatation in Fig. 5 is not markedly greater than that in Fig. 6. L, lumen; P, plicae; M, myosalpinx; $\mathrm{S}$, serosa; vs, vascular space. 


\section{PLATE 1}

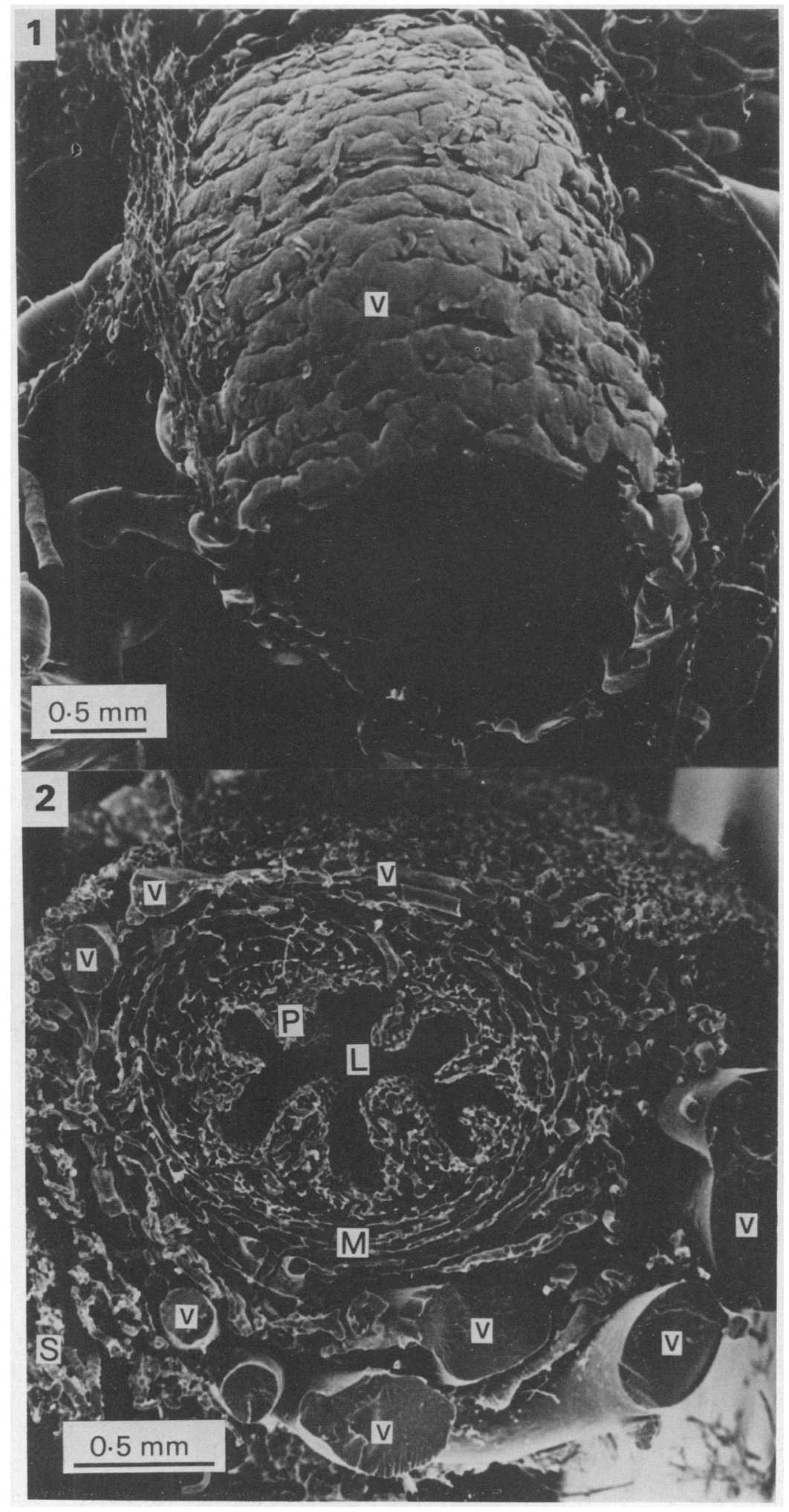

(Facing p. 16) 


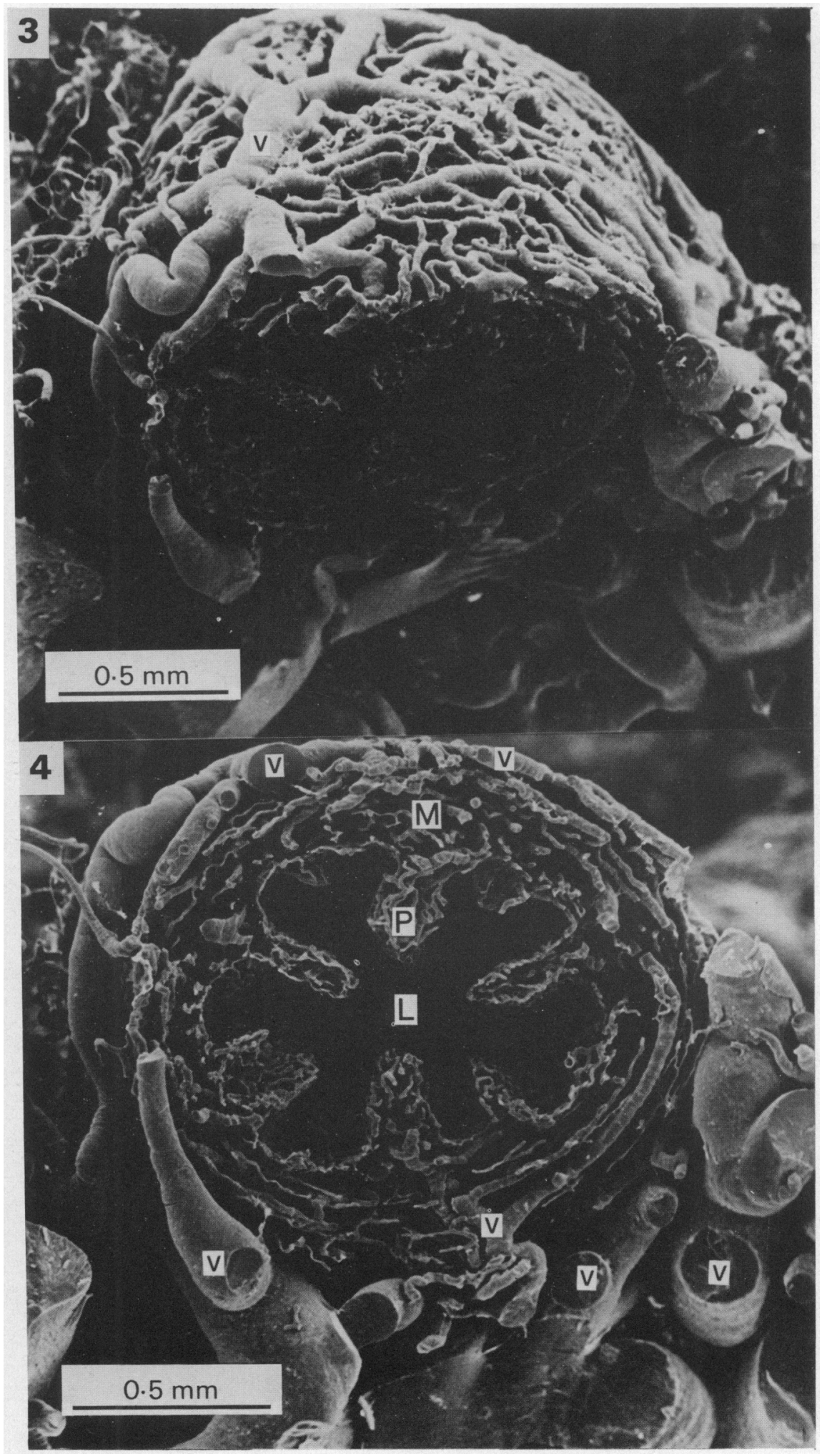




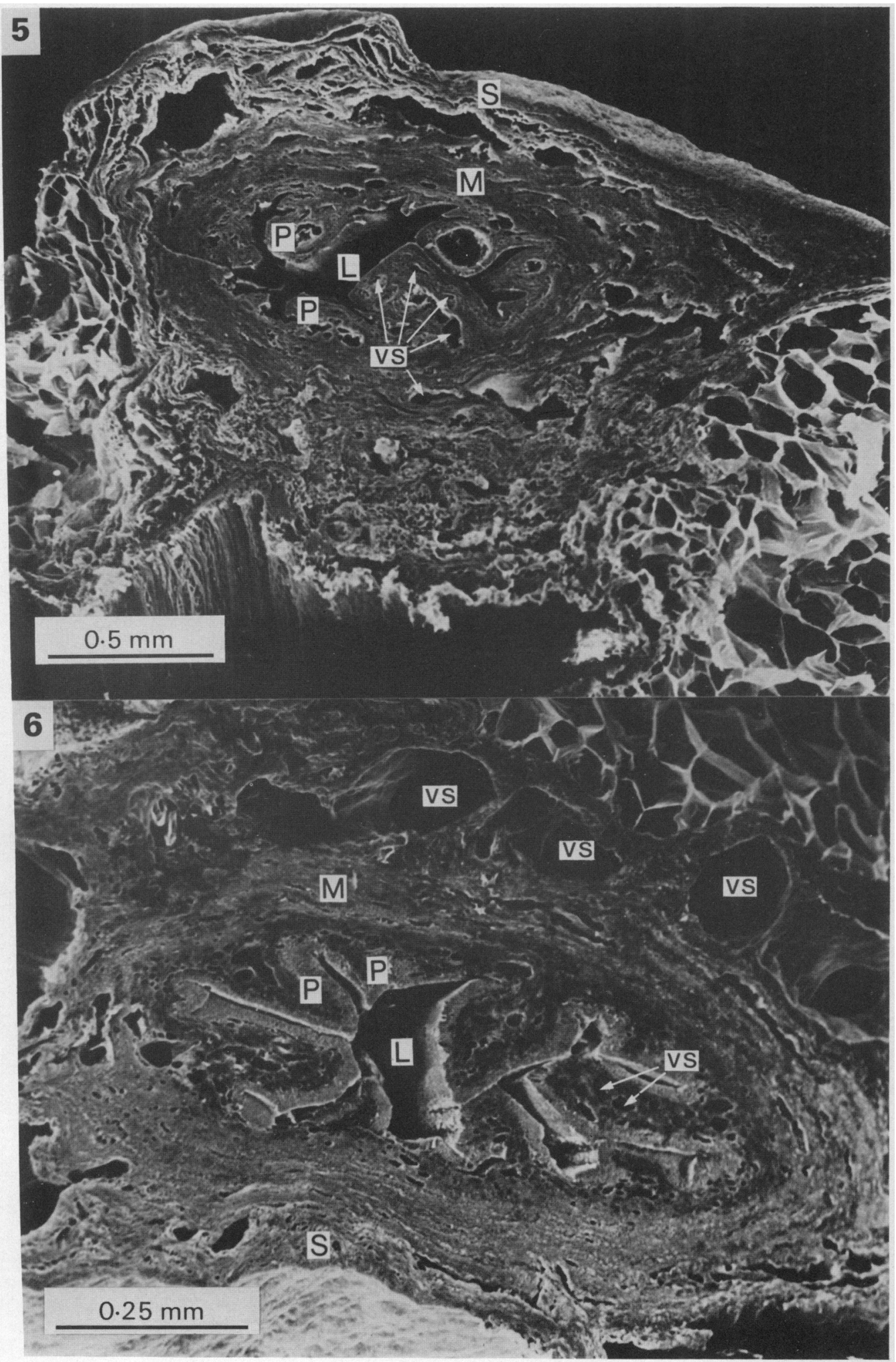


specimens at SEM, printed at $16.5 \times 21 \mathrm{~cm}$ and viewed in a mirror stereoscope (Model ST4, Wild, Heerbrugg, Switzerland). The detailed microvascular pattern was mapped in the photomicrographs, using the criteria of Hodde \& Nowell (1980) to distinguish between arteries and veins, as previously applied to rabbit oviduct corrosion vascular casts (Verco et al., 1983a, b, 1984).

\section{Results}

At dissection after vascular casting and $\mathrm{OsO}_{4}$ perfusion fixation, the occurrence of bilateral ovulation in all rabbits was indicated by blood-filled ovulation sites characteristic of early corpora lutea. Buckling of the oviduct, in which the fimbria and ampulla were rotated towards the uterus about an axis through the AIJ, is due largely to contraction of the mesotubarium superioris. This occurred, as usual, during methacrylate infusion, but in spite of this distortion of oviduct macromorphology, enough segments of isthmus proximal and distal to the uterotubal junction (UTJ), ampulla, proximal and distal to the AIJ, and of fimbria were obtained to define the microvasculature 24 and $48 \mathrm{~h}$ after hCG injection. In both groups of casts, tubal microvasculature was, in general, similar to that reported in control oviducts (Verco et al., 1983a). Isthmic segments exhibited the characteristic subserosal venous plexus and a mucosa richly supplied by arterioles which ramified into capillaries near the apex of a mucosal fold; these capillaries drained down the side of a fold and to the plical core veins which lie deep to the mucosal arterioles. In the ampulla, the architecture was similar to that of the controls, with parallel branching subserosal arteries and veins and a mucosa supplied by arterioles which terminated in capillaries low in a fold or which passed to run along the apex of a fold before terminal ramification; plical capillaries drained into the large veins which originate near the apex of a mucosal fold. As in controls (Verco et al., 1983a), in the fimbria there were parallel branching arterioles and venules; the arterioles, near the margin of a fimbrial fold, divided into a capillary network which drained to the large accompanying fimbrial core veins.

Venous distension, however, was different in the control and hCG-treated rabbits. By $24 \mathrm{~h}$ after hCG injection, ampullary and isthmic subserosal veins (Pl. 1, Figs 1 \& 2) were clearly more dilated in all segments examined than is usually observed in control oviducts (Fig. 2A: Verco et al., 1983a); this was particularly apparent adjacent to the UTJ in two pairs of oviducts. The isthmic luminal area, assessed subjectively from vascular casts, seemed increased (when compared with controls; Fig. 1A: Verco et al., 1983a) in 3 and similar in 2 (Pl. 1, Fig. 2) pairs of isthmic segments. By $48 \mathrm{~h}$ after hCG injection, the venous distension observed at $24 \mathrm{~h}$ was no longer present in the isthmus (PI. 2, Figs $3 \& 4$ ) or the ampulla, the veins resembling those in controls (Verco et al., 1983a). At 48 $\mathrm{h}$, in 3 pairs of mid-isthmic cast segments, increased tubal luminal area was observed.

SEM examination of the cut surfaces of isthmic (PI. 3, Figs $5 \& 6$ ) and ampullary segments after vascular perfusion fixation with $1 \% \mathrm{OsO}_{4}$ revealed smooth-walled empty spaces, i.e. the tubal vascular channels. Isthmic luminal space clearly differed from that in controls in which the luminal space is more a potential than an actual space (Figs 1C \& 2D: Verco et al., 1983a). At $24 \mathrm{~h}$ (Pl. 3, Fig. 5) and at $48 \mathrm{~h}$ (Pl. 3, Fig. 6) after hCG injection, in all proximal and distal transversely cut isthmic surfaces, there was an ovoid luminal space of approximately $450 \mu \mathrm{m}$ maximum diameter (compared with $\sim 250 \mu \mathrm{m}$ in controls: Verco et al., 1983a). Luminal space in the ampulla at $24 \mathrm{~h}$ and $48 \mathrm{~h}$ after hCG injection was not greater than that observed in control oviducts (Verco et al., 1983a). Isthmic luminal mucus was not observed at 24 or $48 \mathrm{~h}$ after hCG injection.

\section{Discussion}

The technique of vascular casting does not significantly alter tubal vascular or luminal dimensions and the casts obtained are, therefore, accurate and readily reproducible plastic vascular skeletons of the oviduct (Rogers \& Gannon, 1981; Verco et al., 1983a). Variations in tubal vasculature after 
oophorectomy (Verco et al., 1983b) when there was reduced venous filling, and in pregnancy (Verco et al., 1984) when there was venous distension, may imply a relationship between local or circulating ovarian or placental hormones and tubal vasculature (Verco et al., 1983b, 1984).

The concentration of oestradiol in rabbit ovarian venous blood rises initially after coitus or hCG injection (Hilliard \& Eaton, 1971; Wu, Blasco, Flickinger \& Mikhail, 1977; Fredericks, Lundquist, Mathur, Ashton \& Landgrebe, 1983); serum oestradiol and progesterone concentrations fall to a nadir at the time of ovulation and remain at low circulating levels during tubal ovum transport. Isthmic oestradiol receptor binding falls to a minimum by $12 \mathrm{~h}$ (suggesting oestradiol receptor saturation) and rises to a peak $72 \mathrm{~h}$ after coitus (El Banna \& Sacher, 1977). In sheep oestradiol caused marked uterine vasodilatation (Greiss \& Anderson, 1970); in rabbits ovarian but not tubal blood flow increased to a maximum $4 \mathrm{~h}$ after hCG injection (Blasco, Wu, Flickinger, Pearlmutter \& Mikhail, 1975). In addition, uterine blood flow in ovariectomized rabbits increased after oestradiol injection (Antonini, Valenzuela \& Harper, 1978). These collected observations, some of which precede ovulation, are consistent with the proposal that the findings in the current study of tubal venous distension at $24 \mathrm{~h}$, with a subsequent decrease at $48 \mathrm{~h}$, after hCG injection are hormone mediated and that the hormone most likely to affect venous capacity is oestradiol.

Resistance to rabbit trans-isthmic luminal fluid flow falls from $40-70 \mathrm{cmH}_{2} \mathrm{O}$, in oestrous rabbits, to $20-40 \mathrm{cmH}_{2} \mathrm{O}$ at $24 \mathrm{~h}$ and $2-20 \mathrm{cmH}_{2} \mathrm{O}$ at $48 \mathrm{~h}$ after hCG injection (Ström, Edin, Dahlstrom \& Ahlman, 1981). Resistance to trans-isthmic flow is unlikely to be a singular property of the uterotubal junction (UTJ) because UTJ excision in rabbits does not result in significantly altered ovum transport or pregnancy rates (Perez, Rajkumar \& Eddy, 1981). In addition, delay in ovum transport at the AIJ is not an intrinsic property of the AIJ because AIJ excision does not interfere with normal fertility in rabbits (Eddy, Antonini \& Pauerstein, 1977; Winston, Frantzen \& Oberti, 1977). Isthmic luminal dilatation 24 and $48 \mathrm{~h}$ after hCG, in the current study, is consistent with AIJ luminal dilatation at the time ova enter the isthmus (Anand \& Guha, 1982) and with the decrease in resistance to isthmic transluminal flow (Ström et al., 1981). This is, however, incompatible with the suggestion that isthmic mucosal oedema leads to the pre-isthmic delay in ovum transport (Hodgson, 1978; Overström et al., 1980; Johns, Buchanan \& Coons, 1982); the accumulation of isthmic extravascular fluid does not fall until $72 \mathrm{~h}$ after hCG injection (Hodgson, 1978; Johns et al., 1982). Accumulation and then the subsequent loss of isthmic tissue fluid are therefore unlikely to contribute to the pre-isthmic delay in and subsequent isthmic ovum transport. The absence of isthmic luminal mucus $24 \mathrm{~h}$ after hCG injection (Jansen, 1978) would, if it were the primary cause of the delay preceding isthmic ovum transport, be more likely to be associated with accelerated isthmic ovum transport. Myosalpingeal activity does not explain the delay in ovum transport at the AIJ, because ampullary ovum transport ceased at the AIJ when tubal muscular activity was blocked (Halbert, Tam, Adams \& Blandau, 1976).

It is therefore suggested that the reported pre-isthmic delay in ovum transport is the result of isthmic subserosal venous plexus dilatation, at $24 \mathrm{~h}$ after hCG, due either to raised venous pressure or reduced venous wall smooth muscle tone. Venous plexus distension, within the limiting perimeter of the isthmic serosal connective tissue, may limit isthmic wall distensibility and, thus, by increasing the mechanical resistance to isthmic luminal transport, prevent isthmic ovum or embyro transport. It is also suggested that the observed isthmic subserosal venous plexus distension may be the result of a rise in tubal oestradiol concentrations. That the delay in pre-isthmic ovum transport is prolonged by exogenous oestrogen (Pauerstein et al., 1974), exogenous oestradiol after AIJ excision (Eddy, Balmaceda \& Pauerstein, 1978) and oestradiol treatment after ovariectomy (Pauerstein \& Weinberg, 1980) supports this suggestion. Finally, it is proposed that the reduction in isthmic subserosal plexus distension $48 \mathrm{~h}$ after hCG is associated with a decrease in mechanical isthmic luminal constriction, with resultant isthmic ovum transport. Therefore, circum-isthmic, oestradiol-dependent variations in isthmic subserosal venous distension seem the most appropriate explanation of the initial pre-isthmic delay in rabbit ovum transport and of the subsequent facilitation of isthmic ovum transport. 
This study was supported by National Health and Medical Research Council grant No. 820048, to C.J.V. We thank Ms Kathryn L. Shepherd for technical assistance and preparation of the photographic plates, and Jennifer Ryan for preparing the manuscript.

\section{References}

Anand, S. \& Guha, S.K. (1982) Dynamics of the ampullary-isthmic junction in rabbit oviduct. Gynecol. Obstet. Intest. 14, 39-46.

Antonini, R., Valenzuela, G. \& Harper, M.J.K. (1978) Uterine blood flow and prostaglandin levels in ovariectomised rabbits. J. Reprod. Fert. 54, 349356.

Blair, W.D. \& Beck, L.R. (1976) Demonstration of postovulatory sphincter action by the isthmus of the rabbit oviduct. Fert. Steril. 27, 431-441.

Blasco, L., Wu, C.H., Flickinger, G.L., Pearlmutter, D. \& Mikhail, G. (1975) Cardiac output and genital blood flow distribution during the preovulatory period in rabbits. Biol. Reprod. 13, 581-586.

Boling, J.L. \& Blandau, R.J. (1971) Egg transport through the ampullae of the oviducts of rabbits under various experimental conditions. Biol. Reprod. 4, 174-184.

Eddy, C.A., Antonini, R., Jr \& Pauerstein, C.J. (1977) Fertility following microsurgical removal of the ampullary isthmic junction in rabbits. Fert. Steril. 28, 1090-1093.

Eddy, C.A., Balmaceda, J.P. \& Pauerstein, C.J. (1978) Effect of resection of the ampullary-isthmic junction on estrogen induced tubal locking of ova in the rabbit. Biol. Reprod. 18, 105-109.

El Banna, A.A. \& Sacher, B. (1977) A study on steroid hormone receptors in the rabbit oviduct and uterus during the first few days after coitus and during egg transport. Biol. Reprod. 17, 1-8.

Fredericks, C.M., Lundquist, L.E., Mathur, R.S., Ashton, S.H. \& Landgrebe, S.C. (1983) Effects of vasoactive intestinal polypeptide upon ovarian steroids, ovum transport and fertility in the rabbit. Biol. Reprod. 28 , $1052-1060$.

Gil, J., Bachofen, H., Gehr, P. \& Weibel, E.R. (1979) Alveolar volume-surface area relation in air- and saline-filled lungs fixed by vascular perfusion. J. appl. Physiol. 47, 990-1001.

Greiss, F.C., Jr \& Anderson, S.G. (1970) Effect of ovarian hormones on the uterine vascular bed. Am. J. Obstet. Gynec. 107, 829-836.

Halbert, S.A., Tam, P.Y., Adams, R.J. \& Blandau, R.J. (1976) An analysis of the mechanisms of egg transport in the ampulla of the rabbit oviduct. Gynecol. Invest. 7, 306-320.

Harper, M.J.K. (1963) Ovulation in the rabbit: the time of follicular rupture and expulsion of the eggs, in relation to injection of luteinizing hormone. $J$. Endocr. 26, 307-316.

Hilliard, J. \& Eaton, L.W. (1971) Estradiol 17 $\beta$, progesterone and $20 \alpha$-hydroxypregn-4-en-3-one in rabbit ovarian venous plasma. II. From mating through implantation. Endocrinology 89, 522-527.

Hodde, K.C. \& Nowell, J.A. (1980) SEM of microcorrosion casts. In Scanning Electron Microscopy, Vol. 2, pp. 89-106. Eds R. P. Becker \& O. Johari. Scanning Electron Microscopy Inc., Chicago.

Hodgson, B.J. (1978) Post-ovulatory changes in the water content and inulin space of the rabbit oviduct. $J$. Reprod. Fert. 53, 349-351.

Jansen, R.P.S. (1978) Fallopian tube isthmic mucus and ovum transport. Science, N.Y. 201, 349-351.

Johns, A., Buchanan, J.D. \& Coons, L.W. (1982) Effect of ovulation on the ionic and water content of rabbit oviduct. Biol. Reprod. 26, 367-377.

Overström, E.W., Bigsby, R.M. \& Black, D.L. (1980) Effects of physiological levels of estradiol-17 $\beta$ and progesterone on oviduct edema and ovum transport in the rabbit. Biol. Reprod. 23, 100-110.

Pauerstein, C.J. \& Weinberg, L.C. (1980) Failure of castration to modify estradiol induced tube locking of rabbit ova. Fert. Steril. 34, 588-592.

Pauerstein, C.J., Anderson, V., Chatkoff, M.L. \& Hodgson, B.J. (1974) Effect of estrogen and progesterone on the timecourse of tubal ovum transport in rabbits. Am. J. Obstet. Gynec. 120, 299-308.

Perez, L., Rajkumar, K. \& Eddy, C.A. (1981) Fertility and ovum transport after microsurgical removal of the utero-tubal junction in rabbits. Fert. Steril. 36, 803807.

Rogers, P.A.W. \& Gannon, B.J. (1981) The vascular and microvascular anatomy of the rat uterus during the oestrous cycle. Aust. J. exp. Biol. med. Sci. 59, 667679.

Ström, C., Edin, R., Dahlstrom, A. \& Ahlman, H. (1981) In vivo studies of the motility of the isthmic segment in the perfused rabbit oviduct. Acta physiol. scand. 113, 491-498.

Verco, C.J., Gannon, B.J. \& Jones, W.R. (1983a) Fallopian tube microvasculature in the rabbit. Aust. J. exp. Biol. med. Sci. 61, 127-138.

Verco, C.J., Gannon, B.J. \& Jones, W.R. (1983b) Fallopian tube microvascular architecture after oophorectomy in the rabbit. Acta anat. 117, 193-200.

Verco, C.J., Gannon, B.J. \& Jones, W.R. (1984) Microvascular architecture of the pregnant rabbit oviduct. Acta anat. 118, 167-170.

Winston, R.M.L., Frantzen, C. \& Oberti, C. (1977) Oviduct function following resection of the ampullary isthmic junction. Fert. Steril. 28, 284.

Wu, C.H., Blasco, L., Flickinger, G.L. \& Mikhail, G. (1977) Ovarian function in the preovulatory rabbit. Biol. Reprod. 17, 304-308. 